\title{
Differentiation of Adipose-Derived Mesenchymal Stem Cells into Neuron-Like Cells induced by using $\beta$-mercaptoethanol
}

\author{
Maeda H. Mohammad* \\ Aesar A. Ahmed \\ Ahmed Majeed Al-Shammari \\ Aseel Khaled
}

Received 9/7/2019, Accepted 5/1/2020, Published 18/3/2020

This work is licensed under a Creative Commons Attribution 4.0 International License.

\begin{abstract}
:
Background: Adipose derived-mesenchymal stem cells have been used as an alternative to bone marrow cells in this study. Objective: We investigated the in vitro isolation, identification, and differentiation of stem cells into neuron cells, in order to produce neuron cells via cell culture, which would be useful in nerve injury treatment. Method: Mouse adipose mesenchymal stem cells were dissected from the abdominal subcutaneous region. Neural differentiation was induced using $\beta$-mercaptoethanol. This study included two different neural stage markers, i.e. nestin and neurofilament light-chain, to detect immature and mature neurons, respectively. Results: The immunocytochemistry results showed that the use of $\beta$-mercaptoethanol resulted in the successful production of neuron cells. This was attributable to the increase and significant overexpression of the nestin protein during the early exposure period, which resulted in the expression of the highest levels of nestin. In comparison, the expression level of neurofilament light-chain protein also increased with time but less than nestin. Non-treated mesenchymal stem cells, considered as control showed very low expression for both markers. Conclusion: The results of this study indicate that adipose mesenchymal cells represent a good, easily obtainable source of bone marrow cells used to developing the differentiation process.
\end{abstract}

Key words: Adipose cells, Differentiation, Nestin, Neurofilament, Neurogenesis.

\section{Introduction:}

Mesenchymal stem cells (MSCs) exhibit an exceptional ability to differentiate into different cell types (1-3). Thus, the use of an approach involving MSCs is promising for the treatment of different neural diseases, because of their ability to produce neural progenitors (4). Neural progenitors and stem cells have been shown to differentiate into different neuronal phenotypes that can potentially be used to treat different human neural diseases (5). Bone marrow (BM) is the first source of choice for obtaining stem cells. However, as the associated technique requires us to extract stem cells from the bone marrow via aspiration (6), there is a need for the use of a less invasive method for stem cell extraction. Adipose tissues act as a source for the unlimited supply of mesenchymal stem cells (7). Adipose tissue is a loose connective tissue located in subcutaneous or visceral depots. It provides energy for metabolism and regulates thermogenesis, immune responses, and lactation (8).

Experimental Therapy Department, Iraqi Center of Cancer and Medical Genetic Research, Mustansiriyah University, Baghdad, Iraq

"Corresponding author: maeda.mohammad@iccmgr.org

*ORCID ID: 0000-0002-0877-2780
MSCs are one of the main components of adipose tissue, and have been isolated and detected in vitro using several methods, including those with low and high specificities (9). Adipose tissue mesenchymal stem cells (AMSCs) can adhere to aplastic culture flasks; thus, they can be grown in vitro as other types of MSCs that exhibit essential characteristics and the capacity to differentiate into multiple cell lineages, which renders them powerful and beneficial after their isolation (10). They have the phenotypic and genotypic characteristics of umbilical cord- and bone marrow-derived MSCs and they express mesenchymal cell markers CD105 and CD44 (11). Moreover, they have high proliferation rates and multiple differentiation potentials that enable them to exhibit the capabilities of umbilical cord- and bone marrowderived MSCs (12). Adipose tissue-derived MSCs reportedly exhibit the potential to differentiate into multiple cell types, including neuron-like cells (13, 14). The differentiation properties of different kinds of MSCs are the same, even if they are obtained from different sources, such as from the umbilical cord, bone marrow, and adipose tissue; therefore, 
the factors and differentiation media involved in the differentiation processes are the same (15). In a previous study conducted by our team, we used $\beta$ mercaptoethanol (BME) to induce neurogenesis in BM-MSCs, to produce neural progenitors, stem cells, and neurons (16). Moreover, nerve regeneration and repair are viable therapeutic approaches either by stem cells or by other approaches such as laser therapy (17). The aim of this research is the identification of a more accessible and alternative source of MSCs that would be highly promising, as it would allow neuronal cells to be produced and used for nerve injury treatment.

\section{Materials and Methods:}

\section{Adipose Derived-Mesenchymal Stem Cell Isolation}

The mice used in this study were provided by the Iraqi Center for Cancer and Medical Genetic Research (ICCMGR), at Mustansiriyah University (animal house unit). The ICCMGR scientific committee approved all the animal procedures. The adipose MSCs were prepared using the modified method described by Yamamoto and Sung $(18,19)$. Briefly, 6-9 weeks old donor male mice were killed by cervical dislocation. Their fur was washed with $70 \%$ alcohol, and the abdomen was exposed. The adipose tissue was separated from subcutaneous sites and cut into small fragments, and then transferred into a petri dish containing serum free minimum essential medium (MEM) (US biological, Massachusetts, USA), supplemented with 500 $\mu \mathrm{g} / \mathrm{ml}$ streptomycin and ampicillin (CapricornScientific, Germany). In the laboratory, under sterilizing conditions, the tissues were washed 3-4 times with phosphate-buffered saline (PBS) and suspended in PBS supplemented with $0.1 \%$ collagenase type I (US Biological, USA) that was pre-warmed at $37^{\circ} \mathrm{C}$, then the tissue was incubated at $37{ }^{\circ} \mathrm{C}$ for 45 minutes with shaking. Then, centrifugation was performed at $1500 \mathrm{rpm}$ for 5 minutes. Then, pellets (containing the cell suspension) were cultured in a growth medium composed of MEM supplemented with $20 \%$ fetal bovine serum (FBS) (Cellgro, USA); it was also supplemented with $100 \mu \mathrm{g} / \mathrm{ml}$ each of penicillin and streptomycin. The cells were cultured in $25 \mathrm{~cm}^{2}$ cell culture flasks and incubated with $5 \% \mathrm{CO}_{2}$ in $95 \%$ humidified air at $37^{\circ} \mathrm{C}$.

\section{Maintenance of Adipose MSCs}

After $24 \mathrm{~h}$, the cells were allowed to become attached to the culture flask surface overnight, and non-adherent cells were removed while changing the medium after $24 \mathrm{~h}$, using growth media composed of 20\% FBS MEM. The culture medium was changed every 3-5 days, until the cultured cells formed colonies of adherent cells, which took about a week to form a confluent monolayer of cells. Later, the monolayer of cells was passaged using $0.25 \%$ trypsin-EDTA (US biological, Massachusetts, USA) (20).

\section{Immunophenotyping of AMSCs}

The cells were seeded at a concentration of 3 $\times 10^{5}$ cells in an 8-chamber tissue culture slide (IWKA, Japan). After confluency was achieved, the cells were fixed for 10 minutes in $4 \%$ neutral buffered formalin.

The fixed slides were first blocked with $1 \%$ hydrogen peroxide $\left(\mathrm{H}_{2} \mathrm{O}_{2}\right)$ for 10 minutes; then, they were incubated with $1.5 \%$ blocking serum for one hour (Santa Cruz Biotechnology, USA). Then, 1:100 diluted primary antibody (mAb anti-CD105 and mouse $\operatorname{IgG} \mathrm{mAb}$ anti-CD44 (US biological, USA) was added and the solution was incubated overnight at $4{ }^{\circ} \mathrm{C}$ in a humidified chamber. The antimouse IgG biotinylated secondary antibody was added after extensively washing cells with PBS. Then, the solution was incubated for one hour, and washed 2-3 times with PBS. Avidin conjugated to horseradish peroxidase (HRP) was added to each slide, which was then incubated in a humidified chamber for another 30 minutes and washed 2-3 times with PBS. The DAB chromogen solution mix was added to the slide for 20 minutes, and it was counterstained in hematoxylin stain for 2 minutes. The slides were covered and examined using a light microscope (Micros, Austria). The assay was repeated in triplicate.

\section{Induction of neuron differentiation for adipose- MSCs}

The adipose-MSCs obtained after the first passage step were induced to differentiate into neurons through exposure to $1 \mathrm{mM} \quad \beta$ mercaptoethanol (BME) (Santa Cruz Biotechnology, USA) for 25, 27, 29, and $34 \mathrm{~h}$; these exposure periods were classified as follows: in early differentiation media, cells were exposed to $20 \%$ FBS MEM media supplemented with $1 \mathrm{mM}$ BME for $24 \mathrm{~h}$. Then, they were subjected to a second round of exposure using late differentiation media, to induce neural differentiation, by exposing cells to serum-free MEM media supplemented with $5 \mathrm{mM}$ BME for different time periods $(1,3,5$, and $10 \mathrm{~h})$ Lei et al., 2007 (21). The differentiated cells were fixed in order to perform the immunocytochemistry assay. Two different protein markers were detected during the differentiation process, using 1:50 diluted nestin (NES), (Santa Cruz Biotechnology, 
USA) and neurofilament light-chain (NF-L) (diluted 1:100), (US biological, USA), and the stained cells were detected using a light microscope. The positive cells were counted, and the percentage was expressed as positive to non-positive cells for the specified marker.

\section{Statistical Analysis}

Statistical analysis of the immunocytochemistry assay data was performed using One Way ANOVA and the LSD test in IBM SPSS Statistics Software (version 20), for determining the average percentage mean values; the difference in the mean values was considered significant if $\mathrm{p}<0.05$.
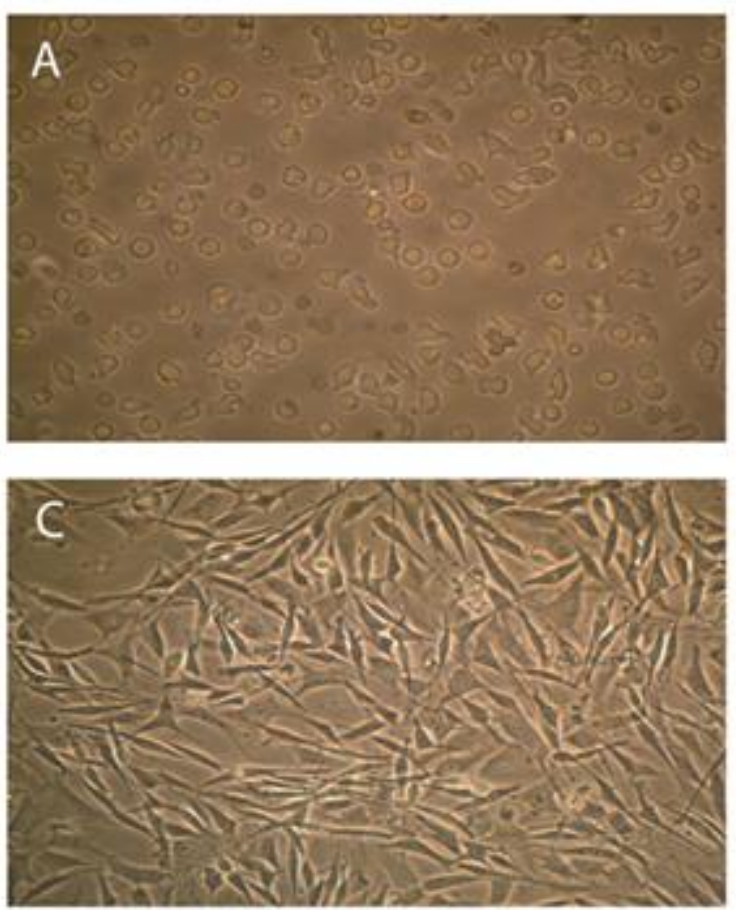

\section{Results:}

Isolation and expansion of AMSCs in culture

The adipose derived MSCs were cultured successfully. After the primary culture process was performed for $24 \mathrm{~h}$, a few cells were observed to adhere to the flask surface and form small colonies, usually after $48 \mathrm{~h}$ (Fig. 1- A and B). The morphology of the adherent cells was fibroblastlike, and they grew to form larger, separated colonies. Then, by the $5^{\text {th }}$ day, the cells became more densely spread; the colonies expanded in size and achieved up to $80 \%$ confluency (Fig.1-C). At the first passage step, the AMSCs formed a homogeneous, confluent monolayer of fibroblastoid-like cells after 5-7 days (Fig.1- D).
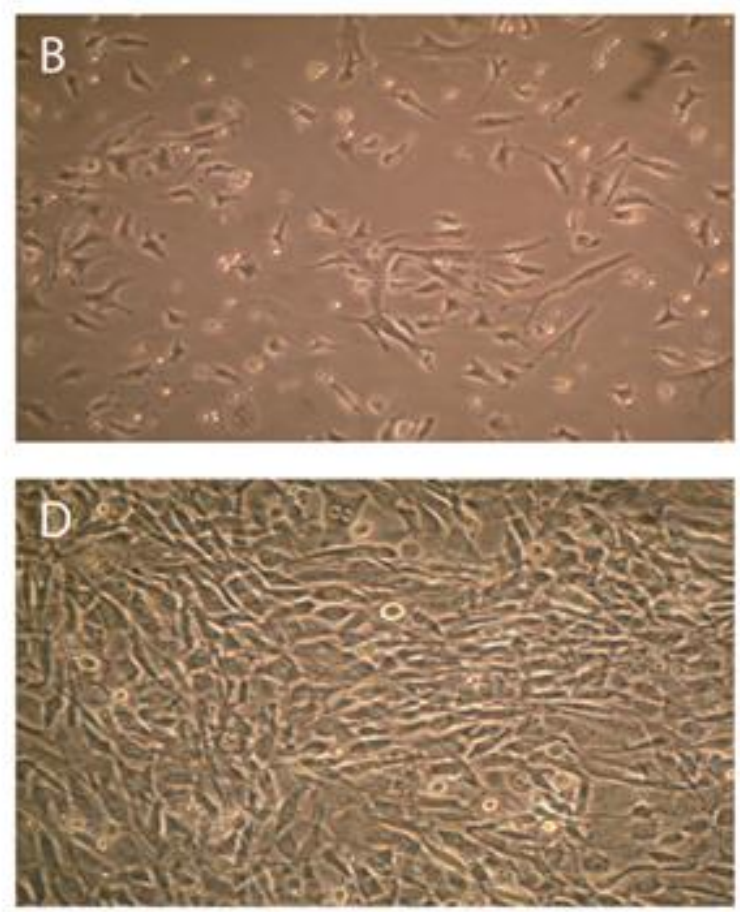

Figure 1. Morphological features of Adipose MSCs (A, after 24 h; B, after 48 h; C, after forming a monolayer; $\mathrm{D}$, after forming a monolayer in passage 1). Phase contract pictures were obtained using an inverted microscope at a $10 \mathrm{X}$ magnification.

Immunophenotypic characterization of AMSCs

AMSCs were studied to determine their immunophenotype, via the immunocytochemistry analysis of the MSC markers CD105 and CD44.
The AMSCs were stained in brown color, as they were positive for both CD44 and CD105 (Fig. 2A and B). 

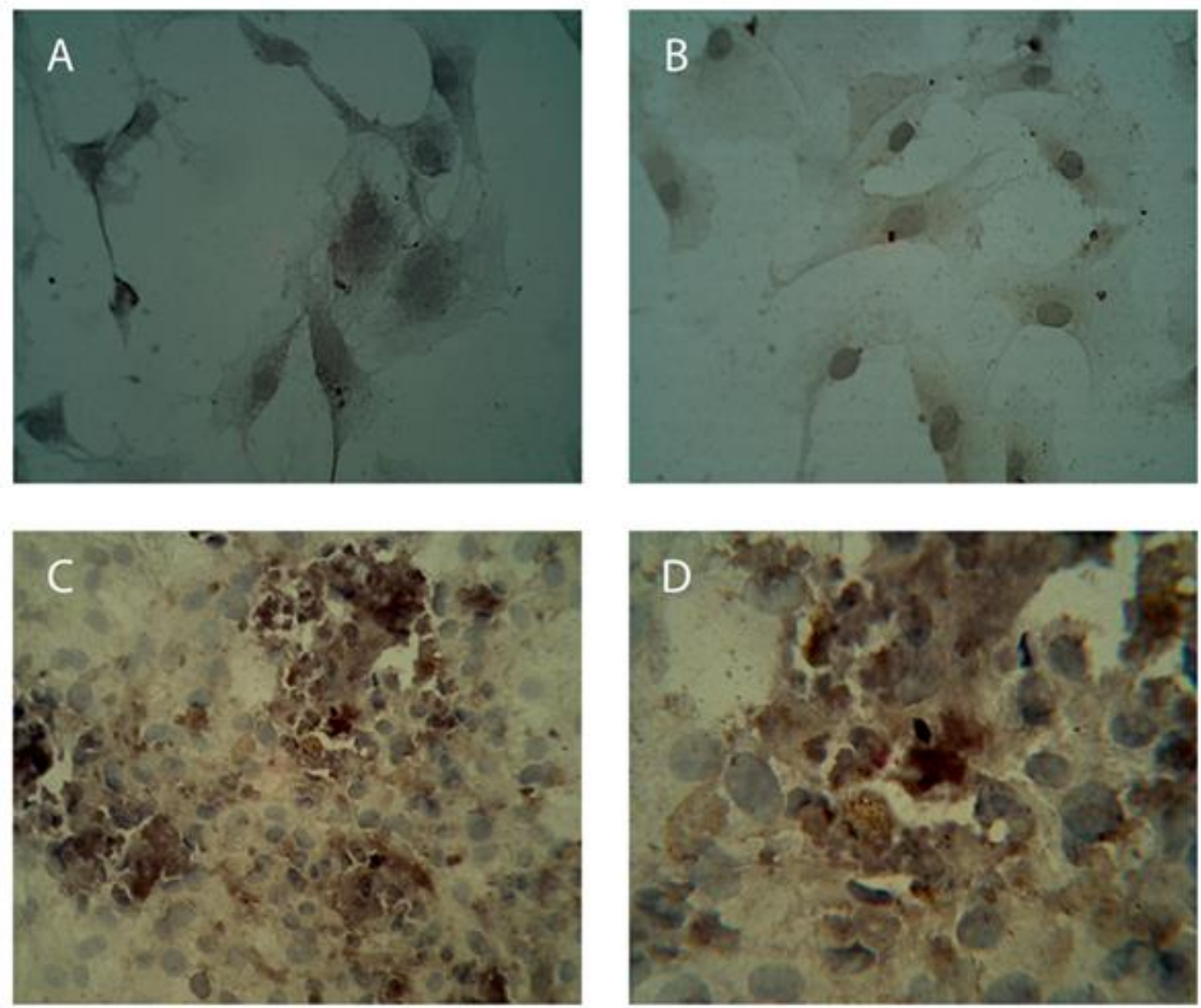

Figure 2. Immunophenotypic assay of AMSCs at the first passage step. (A, negative control at 40X; B, cells positive for $\mathrm{CD105}, 40 \mathrm{X}$; $\mathrm{C}$, cells positive for $\mathrm{CD44}$ at 10X; $\mathrm{D}$, cells positive for $\mathrm{CD44}$ at $40 \mathrm{X}$ ).

\section{Neural induction from AMSCs}

The first passage of AMSCs was carried out to achieve neural cell differentiation, using BME. The morphology of AMSCs after the differentiation process was more spherical than that observed before differentiation, during the first $24 \mathrm{~h}$ (early differentiation media) (Fig. $3 \mathrm{~A}$ and B). Late differentiation media were used at $25 \mathrm{~h}, 27 \mathrm{~h}$ (Fig. $3 \mathrm{C}$ and D), $29 \mathrm{~h}$ (Fig. 3E and F), and $34 \mathrm{~h}$, and cells became differentiated, larger in size, and finally formed branches of neuronal cells (Fig. $3 \mathrm{G}$ and $\mathrm{H}$ ). ICC assay analysis revealed that protein expression was upregulated, when the amounts of NES and
NF-L expressed were $85 \%$ and $23 \%$, after undergoing differentiation for $25 \mathrm{~h}$, in comparison to the levels observed with non-differentiated cells (Fig. 4A and B). Furthermore, the protein expression levels of both markers were increased further at $27 \mathrm{~h}$ and $29 \mathrm{~h}$ (Fig. 4C and D, respectively), and the difference in levels was significant if $\mathrm{p}<0.05$. Higher protein expression levels were observed at $29 \mathrm{~h}(90 \%$ and $40.65 \%$ for NES and NF-L, respectively), compared with those observed with undifferentiated MSCs (as a negative control), as shown in Fig. 5. 

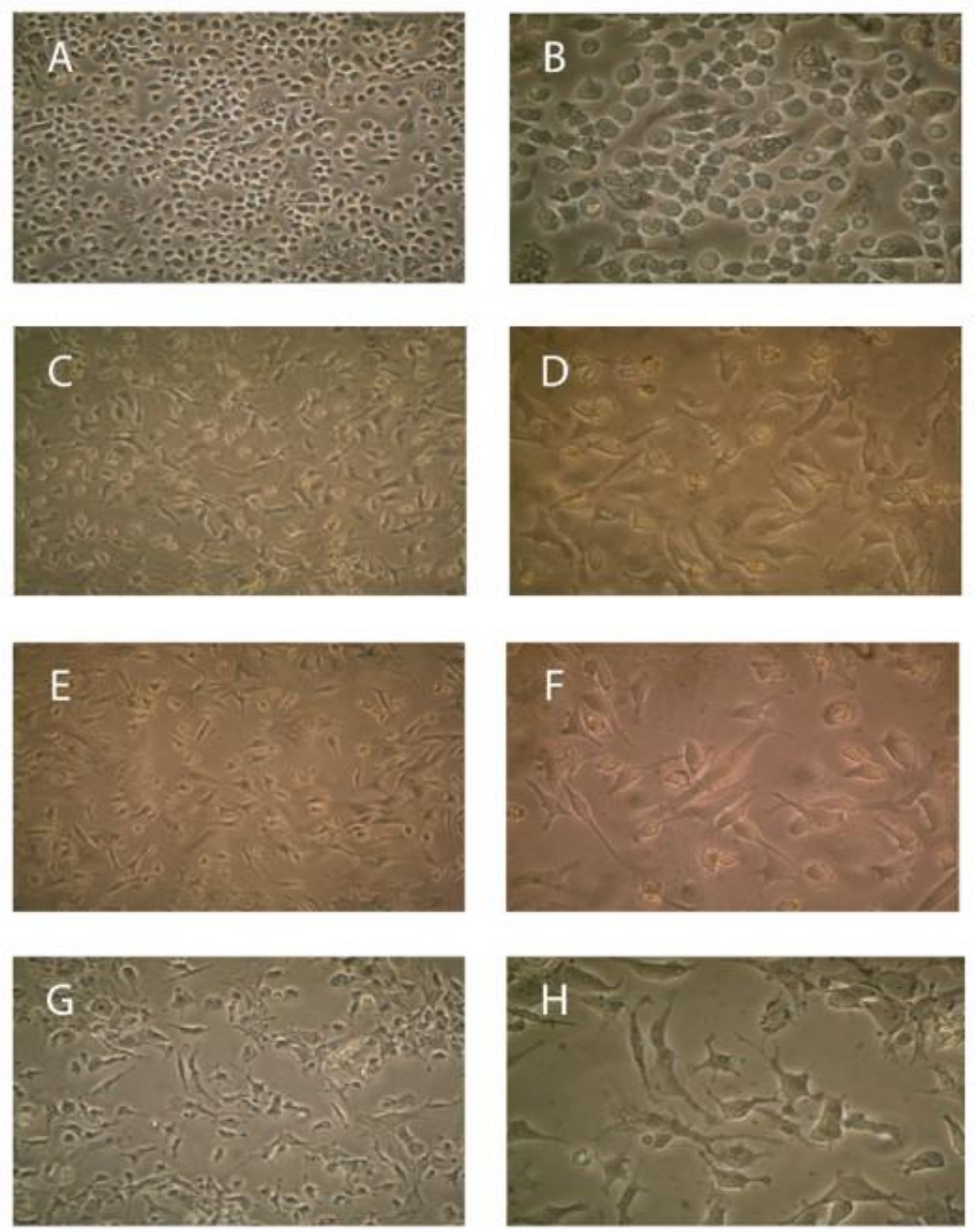

Figure 3. Adipose MSCs observed after the induction of differentiation using BME. A) AMSC morphology was observed to be more spherical after differentiation than that observed before differentiation, after the first $24 \mathrm{~h}$ (early differentiation media) at $10 \mathrm{X} ; \mathrm{B}$ ) the same cells were observed at 40X; C) Late differentiation media after $27 \mathrm{~h}$, at 10X; D) at 40X; E) differentiated cells after $29 \mathrm{~h}$, at 10X; F) differentiated cells at 40X. G) after undergoing differentiation for $34 \mathrm{~h}$, cells were increased in size, and finally formed the branches of neuronal cells, as seen at $10 \mathrm{X}$ and $\mathrm{H}$ ) at $40 \mathrm{X}$. Phase contract pictures were obtained using an inverted light microscope. 

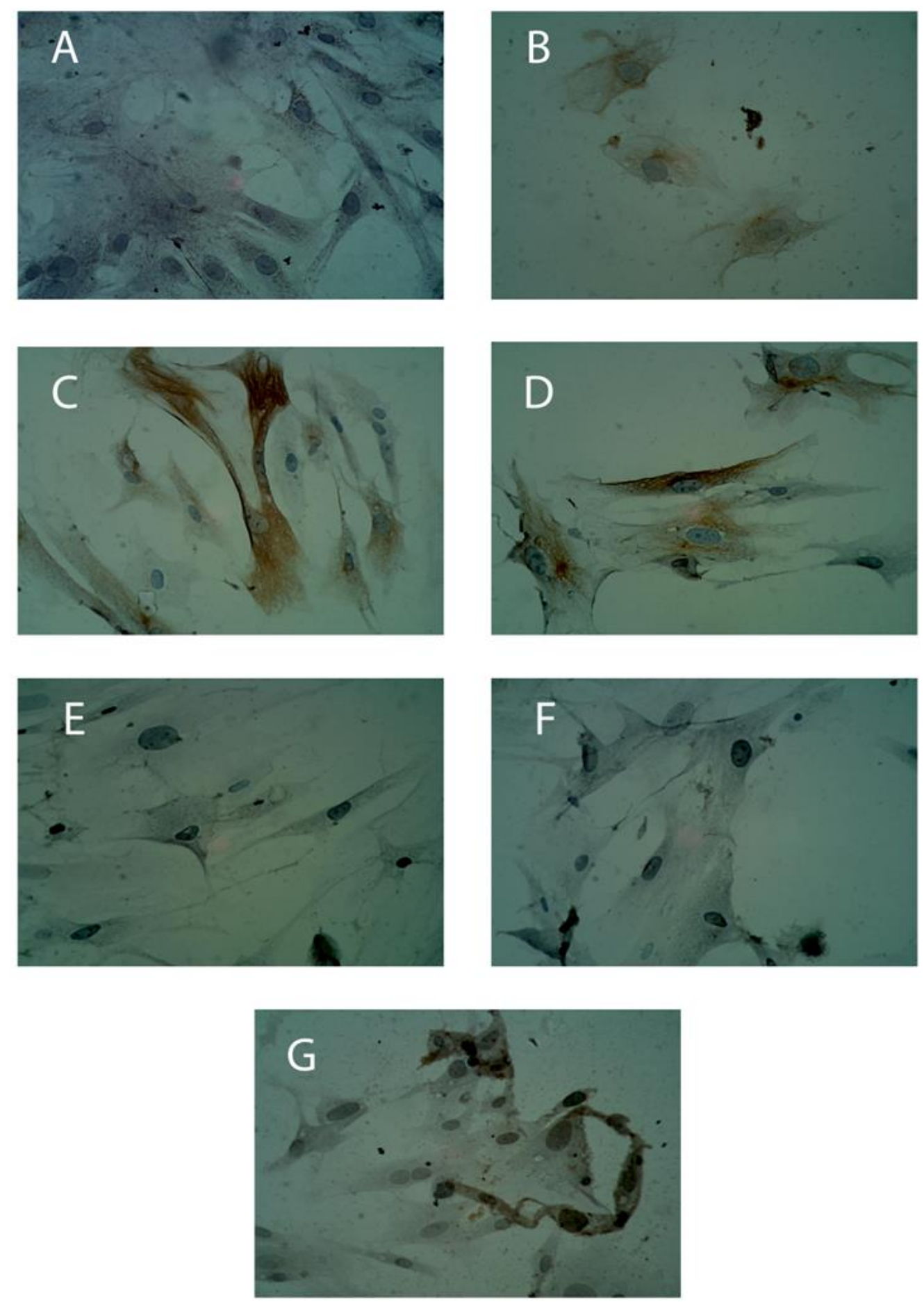

Figure 4. Immunocytochemistry assay for the differentiated AMSCs. (A) Non-induced AMSCs were not found to be positive for both nestin and NF-L, after cell staining; B) induced cells were mildly positive for NES after $25 \mathrm{~h}$; C) differentiated cells were strongly positive for NES after 27h of induction; D) cells were similarly seen to be strongly positive after staining cells for nestin, $29 \mathrm{~h}$ after induction; E) induced cells were stained and found to be negative for the NF-L marker, after they underwent induction for $25 \mathrm{~h}$; F) after undergoing induction for $27 \mathrm{~h}$, the NF-L proteins were mild expressed. G) After being induced for $29 \mathrm{~h}$, cells were strongly positive for the NF-L protein, which proves that the cells had started to transform into neurons. All figures have been obtained at a magnification of $40 X$. 


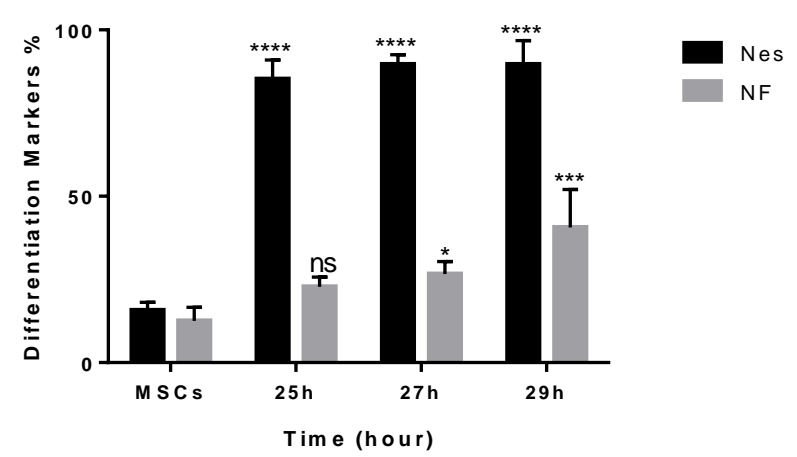

Figure 5. Percentage of cells expressed nestin and NF-L comparing to non-treated cells is shown at different time intervals, after the ICC assay. These results show the expression of the NES marker from the early exposure period onwards, along with their significant difference levels in compare to control MSCs cells; they also indicate the expression levels of the NF protein increased during the late exposure period. All time intervals measured compared to non-treated MSCs.

Note: The symbol "**" indicates that the differences were significant if $p>0.0001$.

\section{Discussion:}

In the current study, we successfully isolated mesenchymal stem cells from subcutaneous adipose tissue that exhibited the same potential of differentiation as that of bone marrow-derived mesenchymal stem cells. Many researchers sourced mesenchymal stem cells from adipose tissues and bone marrow, as they can be used in regenerative medicine $(3,22,23)$. The obtained results of ICC showed that cultured adipose MSCs were positive for mesenchymal cell markers CD44 and CD105. Mesenchymal stem cells derived from adipose tissues contain a fraction of cells that express certain mesenchymal stem cell-specific antigens and do not express hematopoietic stem cell antigens (24). Adipose MSCs are reported to be utilized in various applications more frequently than stem cells from embryonic origins, because of the fewer ethical concerns and low immunogenicity associated with AMSCs (25). Furthermore, AMSCs have attracted attention because they are easy to obtain and can be transplanted safely into an allogeneic or autologous host, and show a higher cellular activity (26). The results of differentiation experiments showed that BME is a good inducer of neurogenesis in AMSCs. Several supplementary trophic factors enhanced cell growth and neuronal differentiation in AMSCs in vitro, including melatonin, BME, CHIR99021, neurotrophin-3, and lithium chloride (27-32). BME, which is an antioxidant reagent, was most commonly used at low concentrations for cell differentiation and therapy (33). Zinc was also suggested to enhance AMSC proliferation and induce neuronal differentiation (34).

Immunocytochemistry results confirmed that cells were differentiated into mature neurons, as the differentiated cells were positive to the neuronal markers NES and NF-L. NES, NF-L, and MAP-2 were found to be the most important markers for the evaluation of the neurogenesis process (16). Moreover, this research found out that there was an association between the marker expressed cells percentage and the observed morphological changes, such as the spherical shape of cells and branches of neural cells.

Another study showed that cells undergoing the neural differentiation process display elevated expression levels of neural progenitor markers, such as NES, along with low expression levels of SSEA4. In addition, these cells were found to be elongated and express chain neurofilament (NF-M) and post-neuronal markers, such as $\beta I I I-t u b u l i n$, NeuN, and MAP2 (35). Furthermore, it was reported that a population of cells in adipose tissues have neuronal characteristics that enable them to participate in the repair of damaged neural tissues. In vivo experiments showed that adipose-derived stem cells could act as a possible source of brain progenitor cells and that they are clinically important in neurological applications (36). Moreover, their efficiency can be improved by the addition of growth factors to media formulations, as this would enhance the efficiency of differentiation of adipose tissue into neural stem cells (37).

\section{Conclusions:}

The protocol described in this study using BME can be used to induce neurogenesis in adipose tissue-derived MSCs in a manner similar to that observed for bone marrow derived MSCs. This is highly advantageous, as the isolation of MSCs from adipose tissues is easier and less invasive than the extraction of bone marrow MSCs. This advantage should encourage the use of adipose tissue MSCs in future applications for the treatment of central and peripheral nervous system injuries.

\section{Acknowledgements:}

This study was supported by the Iraqi Center of Cancer and Medical Genetic Research (ICCMGR), Mustansiriyah University, Baghdad, Iraq.

\section{Conflicts of Interest: None.}

The author has signed on animal welfare statement. 


\section{References:}

1. AL-Qaisy BA, Alwachi SN, Yaseen NY, ALShammari AM. Isolationand Identification of mouse bone marrow derived mesenchymal stem cells. IJCMG s. 2014;7(1):49-55.

2. Alshammari AM, Salman MI, Umran MA. IN VITRO Effect of Differentiation Factors on Accumulation of COL1A1, COL2A1 and CRTAC1 for Chondrogenesis of Mice Bone Marrow Mesenchymal Stem Cells. IJRSB. 2015;3(4):45-56.

3. Majeed C, Al-Shammari AM, Yausif EH, Yaseen NY, Husien AA, Al-Naimi RA, et al. BM-MSCs Differentiated Insulin-Producing Cells Produce More Insulin in Presence of EGF than of FGF. SCD. 2015;5(04):33.

4. Mohammad M, Yaseen N, Al-Joubory A, Abdullah R, Mahmood N, Ahmed AA, et al. Production of Neural Progenitors from Bone Marrow Mesenchymal Stem Cells. SCD. 2016;6(1):1-12.

5. AlShammari AM, Al-Joboury AA, Yaseen NY, editors. Isolation and culture of neuronal stem cells which directed into Purkinje cells to be used for brain damage and epilepsy treatment in mice. Molecular Therapy; 2012: NATURE PUBLISHING GROUP 75 VARICK ST, 9TH FLR, NEW YORK, NY 100131917 USA.

6. Abdullah R, Yaseen N, Saleh S, Mohamed M, AlShammari A. Direct and Sim-ple Method for Mesenchymal Stem Cells Isolation, Culturing and Detection. Int J Stem Cell Res Ther. 2018;5:054.

7. Zheng Y, Huang C, Liu F, Lin H, Yang X, Zhang Z. Comparison of the neuronal differentiation abilities of bone marrow- derived and adipose tissue- derived mesenchymal stem cells. Mol. Med. Rep.. 2017;16(4):3877-86.

8. Colaianni G, Colucci S, Grano M. Anatomy and physiology of adipose tissue. Multidisciplinary Approach to Obesity: Springer; 2015. p. 3-12.

9. Bunnell BA, Flaat M, Gagliardi C, Patel B, Ripoll C. Adipose-derived stem cells: Isolation, expansion and differentiation. Methods. 2008;45(2):115-20.

10. Tsuji W, Rubin JP, Marra KG. Adipose-derived stem cells: Implications in tissue regeneration. World $\mathrm{J}$. Stem Cells. 2014;6(3):312-21.

11. Wagner W, Wein F, Seckinger A, Frankhauser M, Wirkner U, Krause $U$, et al. Comparative characteristics of mesenchymal stem cells from human bone marrow, adipose tissue, and umbilical cord blood. Exp. Hematol. 2005;33(11):1402-16.

12. Wexler SA, Donaldson C, Denning- Kendall P, Rice C, Bradley B, Hows JM. Adult bone marrow is a rich source of human mesenchymal 'stem'cells but umbilical cord and mobilized adult blood are not. Br. J. Haematol. 2003;121(2):368-74.

13. Babiker N, Gassoum A, Musa H, Hamed ALDeaf S, Abdelraheem N, Abdelrahman Arbab M. In vitro Differentiation of Adipose-Derived Mesenchymal Stem Cell into Insulin-Producing Cells. Int J Stem Cell Res Transplant. 2018;6(1):287-93.

14. Huang T, He D, Kleiner G, Kuluz J. Neuron-like differentiation of adipose-derived stem cells from infant piglets in vitro. J Spinal Cord Med 2007;30 Suppl 1(Suppl 1):S35-S40.

15. Han I, Kwon B-S, Park H-K, Kim KS. Differentiation potential of mesenchymal stem cells is related to their intrinsic mechanical properties. INJ. 2017;21(Suppl 1):S24.

16. Mohammad MH, Al-Shammari AM, Al-Juboory AA, Yaseen NY. Characterization of neural stemness status through the neurogenesis process for bone marrow mesenchymal stem cells. Stem cells and cloning : advances and applications. 2016;9:1-15.

17. Al-Shammari AM, Syhood Y, Al-Khafaji AS. Use of low-power $\mathrm{He}-\mathrm{Ne}$ laser therapy to accelerate regeneration processes of injured sciatic nerve in rabbit. ESNPN 2019;55(1):1-.

18. Sung J, Yang H-M, Park J, Choi G-S, Joh J-W, Kwon $\mathrm{C}$, et al., editors. Isolation and characterization of mouse mesenchymal stem cells. TRANSPL P.; 2008: Elsevier.

19. Yamamoto N, Akamatsu H, Hasegawa S, Yamada T, Nakata S, Ohkuma M, et al. Isolation of multipotent stem cells from mouse adipose tissue. "J. Dermatol. Sci. 2007;48(1):43-52.

20. AL-Qaisy BA, Yaseen NY, Alwachi SN, ALShammari AM. Comparison between three different protocols for isolation and culture of mouse bone marrow derived mesenchymal stem cells. IJCMG. 2014;7(1):26-35.

21. Lei Z, Yongda L, Jun M, Yingyu S, Shaoju Z, Xinwen $Z$, et al. Culture and neural differentiation of rat bone marrow mesenchymal stem cells in vitro. Cell Biol Int. 2007;31(9):916-23.

22. Alshammari AM, Salman MI, Umran MA, Yaseen NY. Chondrogenic Differentiation of Mouse Bone Marrow Mesenchymal Stem Cells, First Successes in Iraq. InXX International Congress of Mediterranean Federation of Health and Production of Ruminants, Egypt 2013 Feb (pp. 19-22).

23. Al-Shammari AM, Majeed C, Yausif EH, Hassan A, Yaseen NY, editors. Treatment of Streptozotocin Induced Diabetes Mellitus in Mice by Subcutaneous Intra Adipose Tissue Transplantation of Beta Cells Induced from Bone Marrow Cells. MOLECULAR THERAPY; 2017: CELL PRESS 50 HAMPSHIRE ST, FLOOR 5, CAMBRIDGE, MA 02139 USA.

24. Taha MF, Hedayati V. Isolation, identification and multipotential differentiation of mouse adipose tissue-derived stem cells. TISSUE CELL.. 2010;42(4):211-6.

25. Stonesifer C, Corey S, Ghanekar S, Diamandis Z, Acosta SA, Borlongan CV. Stem cell therapy for abrogating stroke-induced neuroinflammation and relevant secondary cell death mechanisms. Prog. Neurobiol.. 2017;158:94-131.

26. Zhu Y, Liu T, Song K, Fan X, Ma X, Cui Z. Adipose- derived stem cell: a better stem cell than BMSC. Cell Biochem Funct 2008;26(6):664-75.

27. Tu J, Yang F, Wan J, Liu Y, Zhang J, Wu B, et al. Light- controlled astrocytes promote human mesenchymal stem cells toward neuronal differentiation and improve the neurological deficit in stroke rats. Glia. 2014;62(1):106-21. 
28. Abdullah RH, Yaseen NY, Salih SM, Al-Juboory AA, Hassan A, Al-Shammari AM. Induction of mice adult bone marrow mesenchymal stem cells into functional motor neuron-like cells. J. Chem. Neuroanat.. 2016;77:129-42.

29. Joe I-S, Cho G-W. PDE4 inhibition by rolipram promotes neuronal differentiation in human bone marrow mesenchymal stem cells. Cell Reprogram (Formerly" Cloning and Stem Cells"). 2016;18(4):224-9.

30. Narcisi R, Arikan OH, Lehmann J, ten Berge D, van Osch GJ. Differential effects of small molecule WNT agonists on the multilineage differentiation capacity of human mesenchymal stem cells. J. Tissue Eng Part A . 2016;22(21-22):1264-73.

31. Shuai Y, Liao L, Su X, Yu Y, Shao B, Jing H, et al. Melatonin treatment improves mesenchymal stem cells therapy by preserving stemness during longterm in vitro expansion. Theranostics. 2016;6(11):1899.

32. Yan Y-h, Li S-h, Gao Z, Zou S-f, Li H-y, Tao Z-y, et al. Neurotrophin-3 promotes proliferation and cholinergic neuronal differentiation of bone marrow- derived neural stem cells via notch signaling pathway. JLS. 2016;166:131-8.

33. Wong S, Kirkland JL, Schwanz HA, Simmons AL, Hamilton JA, Corkey BE, et al. Effects of thiol antioxidant $\beta$-mercaptoethanol on diet-induced obese mice. Life sciences. 2014;107(1-2):32-41.

34. Moon M-Y, Kim HJ, Choi BY, Sohn M, Chung TN, Suh SW. Zinc Promotes Adipose-Derived Mesenchymal Stem Cell Proliferation and Differentiation towards a Neuronal Fate. Stem Cells Intl. 2018;2018:9.

35. Wei L, Wei ZZ, Jiang MQ, Mohamad O, Yu SP. Stem cell transplantation therapy for multifaceted therapeutic benefits after stroke. Prog. Neurobiol.. 2017;157:49-78.

36. Kokai LE, Rubin JP, Marra KG. The Potential of Adipose-Derived Adult Stem Cells as a Source of Neuronal Progenitor Cells. Plast. Reconstr. Surg.. 2005;116(5):1453-60.

37. Petersen ED, Zenchak JR, Lossia OV, Hochgeschwender U. Neural Stem Cells Derived Directly from Adipose Tissue. Stem Cells Dev. 2018;27(9):637-47.

\section{تمايز الخلايا المزنكيمية المشتقه من النسيج الدهني الى خلايا عصبية باستعمال البيتا ميركابتوايثانول}

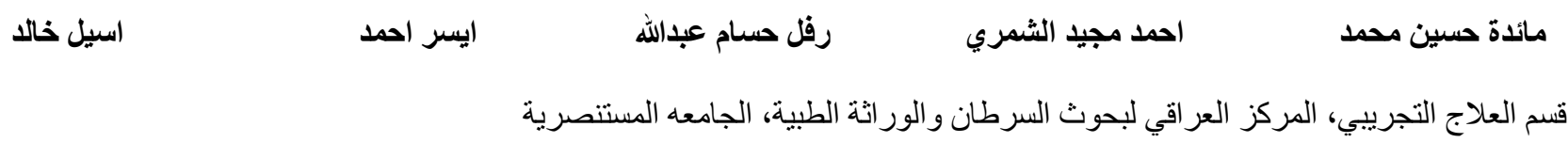

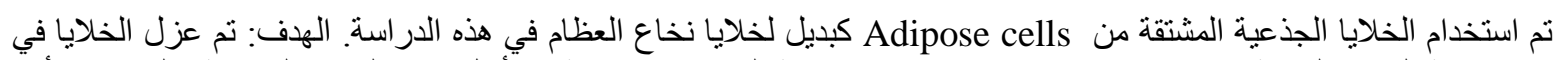

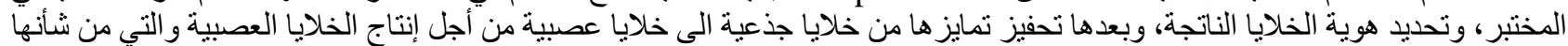

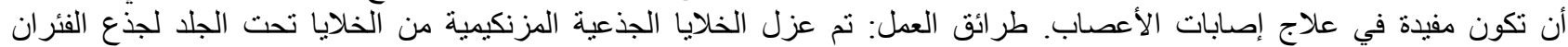

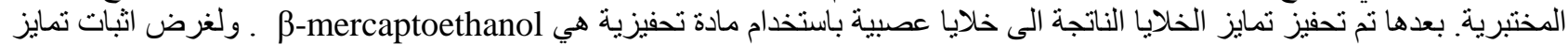

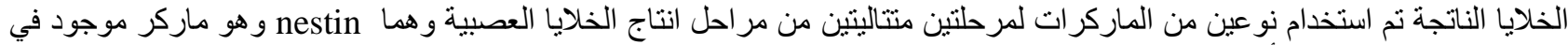

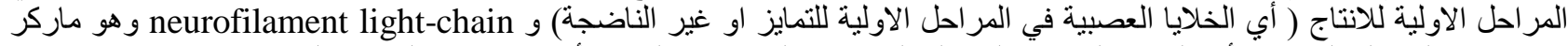

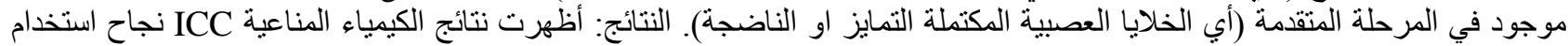

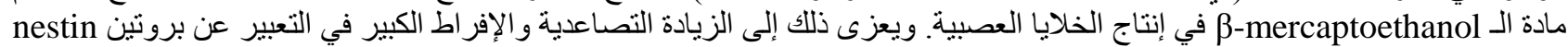

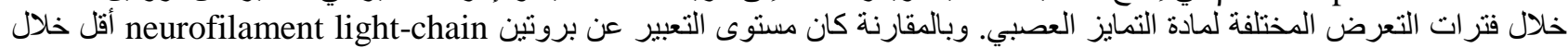

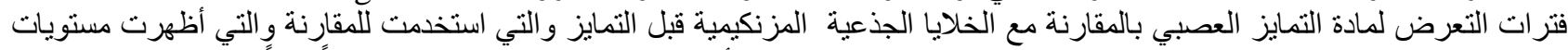

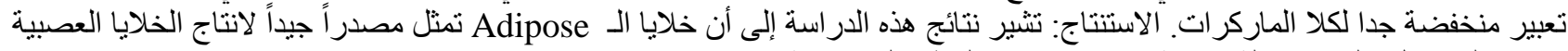
ويمكن الحصول عليها بسهولة مقارنة مع خلايا نخاع العظام المستخذمة عادة في الانتاج.

الكلمات المقتاحية: الخلايا الدهنية، التمايز، Neurogenesis،Neurofilament، Nestin. 